\title{
Bildung as the central category of education?
}

\author{
Didactics, subject didactics, and \\ general subject didactics in Germany
}

\author{
Helmut Johannes Vollmer
}

\section{Introduction}

The following chapter deals with the unresolved issue of the explanatory power and the impact of didactics or the didactics approach on school education which is prevalent in many European countries, especially in northern and western Europe. ${ }^{1}$ Taking Germany as an example, the analysis shows that the Bildungcentred Didaktik ${ }^{2}$ in the traditional form is in a crisis, it is rather powerless as to its orienting function for teacher education and for the professionalisation of teachers. It does not seem to be capable anymore of solving some of the overt problems in preparing teachers successfully and efficiently for the challenges of their future jobs. There are at least three weaknesses (one could even speak of 'deficiencies') which will be analysed in this context, namely (1) losing the content dimension out of sight, (2) lacking empirical orientation, and (3) defining the notion of (Allgemein)Bildung too narrowly as a more or less personal dimension of education and not enough in material or functional terms. In this chapter, I will argue that these serious weaknesses can only be overcome if the content-/subject-specificity of didactics is appropriately taken into account and if the concept of education as Bildung is extended and redefined on more than one level, namely on a personal AND on a functional level, thus preparing teachers and students alike for the challenges of the twenty-first century.

Didactics as a respected and academically acknowledged scientific field can only survive, the central role of didactics for educational theory and practice can only continue to exist, if this identified 'gap' is overcome. General didactics clearly needs to be revised or rather complemented by another scientific approach which is already partly in the process of replacing it in the quest for a cohesive understanding of powerful knowledge and Bildung at a time of global change and of preparing for an unknown future. My claim is that subject didactics is the missing link between the content-oriented academic disciplines at university on the one hand and the educational sciences at large (including general didactics) on the other hand.

Subject didactics in diverse forms and types have evolved over the last 30 to 50 years, from providing teaching recommendations at first into areas of 
scientific inquiry in relation to specific but limited domains of reality and of analysing the world. Significant features of all subject didactics are (1) focus on content-based education within the system of historically and culturally marked subjects in school, (2) empirical orientation in their research and procedures (at least in principle), and (3) development of an overall theory of subject-specific education as Bildung in the double sense (based on personal and functional dimensions).

In the following I will illustrate this dynamic change away from Didaktik/ didactics as a general approach towards subject-specific didactics and their multiplicity of relevance for education of individuals, for acquiring basic insights and powerful knowledge and at the same time the tools for continued learning, for critical self-reflection and relating to oneself as much as to the world. The specific development in Germany stands for the massive incorporation of subject didactics into teacher education and for the theoretical advancement towards a common theory of all subject didactics (under the label of general subject didactics).

In the long run, we need to compare the different varieties of subject didactics within Germany with those in Scandinavia or in other German-speaking countries, but also in France or in Switzerland. By making transparent their commonalities as well as their specific differences and thus identifying their relative contributions to a comprehensive understanding of education in a formal and material sense (cf. Klafki, 1996), will we be able to strengthen and renew the Didaktik/didactics tradition and offer an alternative to the curriculum-based thinking and research as practised mainly in North America and other parts of world outside of Europe. Whether both approaches could be related to each other more productively and could jointly design elements for an extended, strengthened conceptualisation of teacher education and of teacher professionalisation remains to be seen (cf. Hordern, Muller and Deng, 2021). To find out about the potentials and possibilities of such an encounter is exactly the purpose of this project and the book devoted to it. A prerequisite for finding common ground would be an in-depth mutual understanding of each other, of both approaches in their traditional forms as well as in their renewed, modernised theoretical perspectives (based on appropriate conceptual translations or paraphrases; cf. Vollmer, forthcoming). In that way, this chapter could help to outline some points of departure - at least for one of the two strands - and offer links for a future discourse.

\section{Structure of the chapter}

The chapter is subdivided into three major parts. General didactics will be outlined first, describing its achievements and the didactic models which it produced. The fact that these models exist next to each other and that they are not empirically validated led to a crisis in the field which has continued for some time and even increased. Others contradict this evaluation and take 
different counteractive measures so that the future of general didactics is somewhat open today.

Contrary to that, the status of subject didactics has evolved positively over the years, which will be dealt with in the second part. Generally speaking, it is more secure than ever before (for some areas better than for others). The individual branches of subject didactics fulfil an important function in studying education from a subject-based point of view: given the existence of school subjects within the curriculum, they reflect this subject-specific structure of teaching and learning on the scientific level. They have a clearly defined object of study and an array of appropriate research methodologies at hand so that they are beginning to become well established, equal partners as scientific disciplines, acknowledged in the academic world. As such, they have become very influential for teacher education.

In the third part, I will report about the emergence of general subject didactics as a meta-theory. In recent years, it has become clear that the individual subject didactics have much in common, yet that they are also very specific and different in nature. Under the roof of a joint professional organisation (the German Association for Fachdidaktik) the contacts became more intense and systematic, as will be demonstrated. It was only natural that the goals and outcomes of different subjects and that of education as a whole were compared and put into relation with one another: the approaches, procedures, experiences, and results from different subjects and subject didactics were linked across curricular borderlines, so as to identify their specific contribution to a meaningful personal development of the learners and to the construction of powerful, sustainable knowledge, tools, and capabilities as part of a comprehensive education. In this context, the German discourse on Bildung will be introduced, lately defined in a wider sense: distinguishing a more traditional variety (relating to self-formation and self-cultivation) and a more functional understanding of Bildung (relating to the knowledge of the world, preparing for life and work, for participation in society, for socio-cultural and political activities). This reinterpretation of education as Bildung in the double sense implies an active role of the subject as well as that of the teacher; both are considered central and will guide the rest of the chapter.

\section{Didactics in general - general didactics}

Didactics in general deals with the question of what constitutes 'good' teaching, how to plan a lesson well, and how to produce satisfying results among students. Within that frame of reference, the 'what' of teaching (the content) sometimes plays an ambivalent role, whereas the 'how' of institutionalised teaching (the methods and means) is predominantly present in all didactic models. However, decisions about content and methods of teaching are fundamentally dependent on the goals of teaching (and of learning), as defined, set, or strived for by the school, by the state, or by teachers and learners themselves. Those three 
dimensions are central, but in an extended view, didactics also deals with the 'who' (with 'whom'), the 'when' and 'where', and the 'why' or 'what for' (in the long run); traditionally, it deals less with the question of 'How do we know?' (striving for empirical evidence).

Focusing on the case of Germany specifically, the educational sciences cover a large area of topics and research questions all related to education, its conditions and effects in the widest sense, on the formal and informal level, on the personal and institutional level. Many of its subdisciplines want to understand and describe what education is, how it functions under diverse circumstances and how development/progress takes place, also wanting to improve the practice. Didactics is the theory and practice of teaching and learning in school (Jank and Meyer, 2011, p. 16) and beyond (in the space outside, before and after schooling). Others like Coriand (2017) define it more explicitly as a theory about the relationship between teaching and learning, acknowledging the dialectics between instruction (German: Erziehung) and Bildung. Didactics will have to integrate these different facets into its scope of educational thinking all the way down to good lesson planning. In particular, it has to mediate content and pedagogy, individual development with the empowerment of students through meaningful educational experiences and relevant knowledge building. It does so largely independent of content or subject area.

General didactics as a mode of thinking and reflecting about institutional teaching and learning has a long-standing history, starting in ancient times through the influential work of Johann Amos Comenius, with his major work entitled "Didactica Magna", all the way down until today. As a 'science', however, it is struggling for acceptance within the academic world, mainly because of its lack of empirical data (generation) and its normative orientation. Nevertheless, general didactics is still reasonably well established in many universities of Germany today, mainly because of its claimed importance for teacher education. At the same time, it is more and more under attack and in a self-declared crisis.

\section{Didactic modelling}

In general didactics, there are many models offered for characterising good teaching, and many theoreticians working in that field. Yet, didactic modelling is hardly based on empirical research - rather it is predominantly normative and value oriented. Little is known about what really goes on in the classroom or in a particular lesson dealing with a specific topic and taught in a specific way. So we receive little or no new information about educational reality over the years. Nevertheless, many ideas about alternatives in teaching or learning are offered in more or less abstract terms which are only partly helpful for understanding or mastering a concrete teaching/learning situation. General didactics sometimes turns to a particular content item, but only for illustrative reasons, it is not really embedded in subject-matter structures or knowledgeable about them (except when a scholar is a go-between), common issues for all learning and 
structural conditions for all teaching are addressed like general processes or general assumptions about teaching and learning, perceived obstacles or injustices, potential contradictions, etc. General didactics helps to reflect those structures and conditions and to relate them to basic goals and educational values, speculative at times, but that is its strength as well: it can offer a critical corrective to the actual teaching and learning practice. And this critique is normally not turned prescriptive. Meaningful modelling, however, or lesson planning requires more.

It is perhaps surprising, but understandable, that general didactics is being replaced to some extent by approaches of educational psychology with their highly sophisticated models of teaching, interaction with other variables, and outcomes orientation. Yet it is exactly the philosophical dimensions of education (goals, norms, values, social conflicts) that keep didactics in business. ${ }^{3}$ As to the growing crisis, some influential representatives like Hilbert Meyer (forthcoming) saw it already develop over the last years; he lists the following four indicators:

1 professorial posts formerly dedicated to general didactics are more and more redefined for empirical classroom research; alternatively, the posts are cancelled altogether. This shows that general didactics has not succeeded to give itself an empirical basis, in spite of recent efforts (cf. Rothgangel, 2017, pp. 151-152).

2 The time allotted to general didactics within teacher education curricula is also shrinking. Whereas it was self-understood for years that all teacher students had to take a course in that field and had to participate in one or two seminars on that topic, this is not the case anymore. In many universities, there are no didactics lectures offered at all; rather, students turn to subject didactics right away. And where general didactics is still being offered as an introductory course, subject didactic topics and programmes are quickly taking over.

3 Many representatives of subject didactic disciplines do not relate to the discourse in general didactics anymore; ${ }^{4}$ instead, they rely on their own extensive research results and their own models of teaching, which are quite differentiated by now, though content-bound.

4 Educational psychology is gradually taking over the core domains of general didactics. What used to be a unique object of didactics for more than 200 years turned into a topic of psychology, almost unnoticed and without protest or public debate. Another candidate to threaten general didactics could be what is called 'empirical teaching-learning-research' or indeed subject-matter didactics itself, with its new extension of general subject didactics (discussed later in this chapter).

\section{The future of general didactics}

Other representatives in the field of general didactics strongly contradict and oppose this critical view - e.g. Meinert Meyer (2016) or Ewald Terhart (2019). The first one, co-founder of a newer variety of didactics (Bildungsgangdidaktik, 
Meyer and Reinartz, 1998), has rejected this perspective for a long time (Meyer and Meyer, 2009). The second one, the author of many influential publications, also sees no need to question the status of didactics within the German academic landscape (e.g. Terhart, 2018). Others, like K. Zierer, editor of the Yearbook on General Didactics, or N. M. Seel, even claim that 'general pedagogy' (their translation of Allgemeine Didaktik) is indispensable in view of the unsettled issues of 'good' teaching or 'instruction', as they prefer to label it (Seel and Zierer, 2018). ${ }^{5}$ They quote G. Heursen (2005) who pointed out that (general) didactics will only survive ("experience a new springtime"), if the integration of empirical teaching-learning research into the discipline would be successful. This seems exactly what, according to Seel and Zierer, is starting to happen: overcoming eclecticism, studying general educational models empirically (Wernke, Werner and Zierer, 2015). It should be noted, however, that the empirical methods applied here are mainly qualitative and 'judgemental' (cf. Zierer and Wernke, 2013). The authors also mention Hattie's meta-analyses (2008) as a proof for this development, plus closer links between general didactics and instructional design. All of these processes indicate to them that general pedagogy is "capable of handling the developments in the scientific field and of staying the central discipline for the education of teachers in the future" (Seel and Zierer, 2018, p. 388; my translation). ${ }^{6}$ And indeed, basic didactic models will continue to be of relevance and helpful in the first phase of teacher education, at least for beginners.

Interestingly enough, there is another new approach of comparing the different "didactic models" in a meta-theoretical perspective. Scholl (2018) identified almost 100 competing designs within Germany over the last 100 years. According to him, the pending crisis was also caused by general didactics itself, namely through the fact that the models hardly make explicit reference to one another, nor do they build on preceding suggestions. Additionally, none of the models reflects classroom reality completely and thus cannot claim to represent the discipline as a whole. Scholl takes resort to a fundamental theory of communication (as part of a comprehensive systems theory of society) formulated by Niklas Luhman (1992), in order to develop a common frame of reference against which he then re-analyses and classifies the different models, focusing on the most powerful and influential ones (such as Heimann, Otto and Schulz, 1979; Schulz, 1991, or Klafki, 1996) as prototypes for particular aspects within the overall framework. He comes up with a meta-structure of ordering the field, subdivided by components like content, time sequence, and socio-communicative order (Scholl, 2018). ${ }^{7}$ It remains to be seen whether Scholl's study will cause new debates and disciplinary self-inquiry; certainly it has the potential to do so. ${ }^{8}$ In this context, we can look forward to a new edition of the book on Didactic Modelling by Jank and Meyer, announced for 2021. It cannot be denied that some basic models about lesson planning and good teaching as well as recent introductions into general didactics (e.g. 
Coriand, 2017; Terhart, 2019, or Jank and Meyer, 2011, 2021) have a clearly orienting function and will be important also for future generations of teacher students and teachers.

\section{Curricular perspectives}

There is good reason to believe that general didactics will continue to exist, though in a different form. Its relevance might reduce, since its educational tasks and goals are (partly) incorporated by other disciplines, as shown previously. What is the general within general didactics? It all depends on whether the discipline can contribute to defining the general goals and dimensions of education, the common core of institutionalised teaching and learning on the conceptual, the content, and the communicative level. And this is more than describing the tasks and purpose of educational practice: it requires to mediate explicitly between the individual and society, without "sacrificing" the needs or demands of the individual to those of society or vice versa (cf. Benner, 1987, p. 123), without losing one or the other out of sight or stressing one dimension of education more than the other. This is an issue that general subject didactics (see later in the chapter) also faces in a similar way, as rightly observed by Terhart (2018, p. 89): if we re-discover Bildung and its relevance in both directions "as the core principle for determining which tasks a school should undertake and which ones it should reject" (von Hentig, 1996, p. 13), it would give us the power to judge what is important, valuable, and "good" (p. 13). Ideas like these are still rather vague or even fuzzy, they would have to become more concrete or even operationalised on the personal and on the content level, e.g. by defining a shared system of values and a shared base of knowledge as key competences.

At this point, the work of Baumert (2002) becomes important. His educational theory is an important provider of new theoretical considerations for general didactics (as much as for general subject didactics, by the way). Based on the existence of school subjects, Baumert acknowledges them as historically grown organisational units. But he also qualifies them as social and intellectual organisers of reality, of providing access to the world, of encountering and experiencing it. Baumert describes their potential for becoming restructured into groups of related subjects with a similar underlying type of orientation or logic: he distinguishes four types of 'rationality' or ways of relating to the world (2002, p. 113), namely

1 Cognitive-instrumental modelling of the world (math, natural sciences ...)

2 Aesthetic-expressive encounters with and shaping of the world (language/ literature, music/fine arts (painting/visual/graphic art), physical expression)

3 Normative-evaluative approaches towards economy and society (history, economic education, politics/social/legal studies)

4 Tackling problems of constitutive rationality (religion, philosophy). 
These rationality types have already been applied for subdividing areas of literacy within the PISA approach of large-scale testing and of comparing achievement results internationally. According to Baumert, they represent something like the "structure of an international core curriculum" (2002, p. 108). They are amazingly close to the idea of a general education (Allgemeinbildung) based on these structures (even with explicit reference to Humboldt; Baumert, 2002, p. 107). In our context, suffice it to say that Baumert strongly criticised specific didactic models like those of Klafki (e.g. 1996) or Blankertz (1973), because they wanted to overcome the issue of a curricular canon in an unrealistic way and to question the future of subject didactics (even as domain didactics, for example) and were against changes in curriculum development accordingly. Instead Baumert recommends an orientation along the lines of Wilhelm Flitner (1961) who was the first to formulate the aforementioned types of 'rationalities' as modes of world encounter (Modi der Weltbegegnung).

As a provisional result, the very idea that the general within general didactics could be identified and named positively in terms of goals and content seems to be problematic. Rather, we have to accept that there are alternative ways to perceive, experience, and structure the world and thus to relate to it educationally, as persons, teachers, or learners. Similarly, it seems somewhat naive to think that one can renounce a certain canon of subjects or subject-matter areas altogether. This insight and conviction underline the need for subject-matter didactics and support their theoretical and practical work.

\section{Subject-matter didactics}

Subject-matter didactics (or short: subject didactics) ${ }^{9}$ has many branches according to the specific area of focus and expertise, developed over the last 50 years and well established by now as academic disciplines. What helped to secure this status was a clearly defined object of study and an increasing orientation towards empirical research plus the insight into its importance for teacher training. Whereas the curriculum movement of the 1960s and 1970s failed to fulfil its own claims to model the world as a whole for learning purposes in school, subject didactics were more successful because they kept to school subjects as part of the existing (state) curriculum. They created teaching materials, gave advice and made recommendations, developed teaching models, and finally turned to empirical studies (e.g. teacher and learner attitudes, motivation, teaching/ learning preferences, feedback practices, etc.). Later they dealt with questions like transforming new academic insights into teachable content or restructuring the subject-specific curricula altogether, in view of PISA and operational definitions of educational success. Also the increasing diversity of the student population became a major concern. We can identify the different individual subject didactics like biology or history didactics as separate disciplines, dealing with the teaching and learning of a specific, more or less defined area of social reality, in school and beyond. But at the same time, they all share a large number 
of similar, comparable, unresolved issues which are waiting to be tackled and solved. The assortment of research methods to be applied for scientific inquiry and practical studies is somewhat limited. Yet, there was little cohesion among the different subject didactics; as a matter of fact they are only beginning to find out about their differences and commonalities under certain comparative perspectives, stimulated by the existence of a newly developed scientific approach under the name of general subject didactics (GSD, see later on in the chapter).

\section{Subject didactics as scientific disciplines}

According to self-definitions of representatives from different subject didactics, there are three major tasks identifiable for all of them:

1 Reflection and analysis of the school subject with all its dimensions (from institutional matters via content issues to new goals, experimentation with or theoretical justifications of teaching/learning methods).

2 Improvement (even "optimisation") of subject-specific teaching, learning, and education, including analysis and management of inequality problems and enabling Bildung as a process and product for all through dealing indepth with subject-based issues.

3 Mediation between academic knowledge, subject-didactic knowledge and the fields of application on the personal and public level (including subject didactics for the media, for industry, museums etc.) - areas often neglected, but also not well defined. These dimensions are left aside in this chapter.

Thus, the individual subject didactics describe, analyse, and theorise subjectspecific teaching and learning in all its forms, including the relevant societal as well as anthropological conditions (cf. Schneuwly, 2011). Historically speaking, subject didactics as disciplines developed from agencies of reflection and counseling, based on issues of normativity and societal values, into empirically oriented scientific fields, responsible for the selection and justification of goals, for the preparation of teachable content (within the framework set by society and politics), for the successful mediation of relevant knowledge and skills (including support for special needs), and for studying the variables and conditions that influence the teaching-learning process. Given the myriad of tasks, it is assumed that up to 200 different subject didactics exist as academic fields of study, including the ones for all the vocational subjects and special learning areas (without necessarily being labelled as such). Each one has a clearly marked object of study, equipped with appropriate methodologies and built-in forms of self-reflection and self-evaluation. Some disciplines are better anchored within universities or colleges of education than others. Some constituted themselves later or developed slower, others set the pace, also in theoretical reflection and research output, and in the numbers of young emergent researchers waiting to become initiated into their specific subject area. The research balance is 
impressive, though biased by qualitative approaches (given the number of publications and third-party funding from esteemed research agencies).

One could demonstrate how subject didactics is positioned between the academic content disciplines (Fachwissenschaften) on the one hand and the educational sciences in their different forms on the other hand (Abraham and Rothgangel, 2017). This last area relates particularly to general didactics as opposed to subject didactics. Subject didactics participates in both areas of research and discourse mentioned, but over the years it has become independent and autonomous in its own self-definition and achievements. The different subject didacticians are also actively involved in analysing and supporting solutions for problems existing in their respective subject area; advising school districts, teachers, or ministries and developing appropriate policy papers or teaching material(s); also making suggestions for cross-curricular topics or projects (like data management, digitalisation, inclusion, or teacher education). All of this is also influenced by the institutional context in which they operate and which they serve, namely whether it is part of a comprehensive Faculty of Philosophy, a Faculty of Education, a Teacher Training College or a University of Applied Sciences or Arts. These different types of embedding will have some effect on the self-definition of the subject didactic disciplines and their modes of self-presentation and legitimisation.

The status of subject didactics in the academic field is largely secured within Germany (although there are still some tendencies to occupy some posts consecrated for didactics with pure scientists or empirical educational researchers). Each of them has developed its own self-concept, each one presents itself scientifically at conferences (either separate or together with the teachers in the field), all of them publish their own book series and collection of materials, many of them edit a peer-reviewed journal, except where the development of the discipline is less advanced. So, the need to exchange between them, to see how a neighbouring subject discipline is operating, whether there is overlap and common ground between them, and last but not least what the specific challenges of the future are, has developed quite naturally for almost 25 to 30 years.

\section{Relationship between different subject didactics}

Within Germany, individual subject didactics have cooperated with one another on the national level for a long time, formally so under a common roof of a professional organisation named Association for Fachdidaktik (Gesellschaft für Fachdidaktik, GFD, co-founded by the author in 1999, with forerunners to that; cf. Vollmer, 2017). The GFD comprises almost 30 professional membership associations by now which meet twice a year, hold regular bi-annual conferences, try to influence research organisations and politics in their agendas, and above all provide platforms for the internal discourse among all the different subject didactics which profit enormously from this exchange. In addition 
to a book series (Fachdidaktische Forschungen, with over 20 volumes by now), the GFD also publishes a new international journal (online, peer-reviewed, in English only) entitled Research in Subject-Matter Teaching and Learning (RISTAL. org), which offers a global platform for discussing subject-didactic issues and research findings worldwide.

Teacher education especially profits from this dynamic cooperative movement. The ongoing discourse among the different subject didactics has already led to discoveries of mutual interests, to joint scientific actions or theoretical clarifications. With a spreading number of professorships for subject didactics and their relatively secure institutional embedding, the status of subject didactics and its role as an academic partner and a serious research co-operant is more or less acknowledged. However, communication and exchange between general and subject didactics as a whole is still underdeveloped and needs to be better promoted within the next years.

Through all of these measures and interactions a high level of conceptual and organisational exchange was reached, leading to an infrastructure among the different individual subject didactics which is strong and productive, and which respects the differences between them. Simultaneously, many commonalities like research topics, research methods, goal settings, use of reference systems, balance between theoretical and practical work, etc., are identified and mutually acknowledged. The same is true for subject-didactic contributions to teacher education (including offers for in-service training) and to teacher professionalisation, which becomes more and more subject-specific (e.g. Prediger, Leuders and Rösken-Winter, 2017). This is exactly the area where subject didactics could cooperate extensively with the educational sciences and already does so to some extent (cf. Cramer and Schreiber, 2018). What does a teacher need as a knowledge and competence base for becoming and staying a good professional in the twenty-first century? This is a question concerning many disciplines and is discussed in many parts of the world. In dealing with this question, the educational sciences and particularly general didactics plus subject didactics could contribute substantially: their different scientific approaches and findings could interact productively (cf. Abraham and Rothgangel, 2017; Rothgangel, 2017; Vollmer and Klette, forthcoming).

\section{General subject didactics}

Again, the central question has to be raised: what is the common good among all the different school subjects and the subject didactics related to them? Can one identify a general educational strategy or consensus and a common goal among them? And how does each of them contribute to such a common educative purpose? Questions like these originate from the need to look beyond one's own disciplinary boundaries, comparing and generalising different subject didactics as to their structures, procedures, practices, and insights, and finding out what they share, but also what distinguishes them and how each contributes 
to the overall education of an individual - because of or in spite of their distinctive differences. To put it metaphorically: answers to these questions require us to step onto a higher level of observation in order to see and compare the activities and results of the different individual subject-matter didactics. This is exactly what constitutes general subject didactics (GSD): it is based on several columns, which can be defined as levels of 'observation' or research, related to the theory of science by Niklas Luhmann (1992). Applied to the topic of subject didactics, the three levels distinguished by Luhmann are as follows:

1 First order observations are, for example, observations of teachers and pupils in subject-specific teaching and learning processes.

2 Second order observations are, for example, research within subject didactics, in which the observations between teachers and pupils in subjectspecific teaching and learning processes are observed on their part.

3 Third order observations are, for example, research on the level of general subject didactics, where the observation is now directed towards the respective research and theory-building in subject didactics and how they arrive at their findings through observing the subject-specific teaching and learning processes taking place in the classroom.

This last level involves scientific re-analysis, namely comparison between different subject didactics and their theories (bottom-up movement) plus the construction of theoretical insights based on comparison or related to subjectbased education as such (top-down movement). These processes lead to a Theory of Subject Didactics at the same time (Rothgangel, 2020; Rothgangel and Vollmer, 2020). The term 'GSD' and the concept it denotes (in German: Allgemeine Fachdidaktik) is not easy to translate into smooth and comprehensible English. Yet, we have no other choice than to paraphrase and contextualise it, if we want to try and make us understood by others and comprehend each other in the mutual socio-cultural embeddedness of our thinking altogether.

The cooperation among the different subject didactics as academic disciplines has already led to the establishment of many interdisciplinary research groups and activities across subject borders, within universities or faculties and also within the Association for Fachdidaktik (GFD) itself. One group has been working for some time now on finding out about the self-concepts, the research foci, and the state of theoretical reflection in the individual subject didactics. Parallel to that, attempts at defining what a particular subject-specific view of school education is or could be (as opposed to a general, philosophical view of education as such, independent from subjects) have been advanced theoretically. Both movements together led to the formation of this new scientific approach, general subject didactics. The initiating research project was formed by six scholars belonging to five different subject didactic backgrounds as their fields of expertise: namely, German as a Mother-Tongue Didactics, Biology Didactics, Music Didactics, Didactics of Religious Education, and English as a Foreign Language Didactics. 
As they tried to look at the achievements and the deficits of the individual didactic disciplines, it became clear that one cannot do this just from the outside: that the project required cooperation from within the subject didactics themselves in self-describing and presenting their view of their specific approaches and ways of looking at the world, of modelling their insights and the findings of their neighbouring disciplines and qualifying their own contributions. Accordingly, these self-reports were then compared and analysed as to their commonalities and differences. In spite of the fact that general subject didactics is a fairly young scientific theory, there are already two major book publications out on the market (Bayrhuber et al., 2017, and Rothgangel et al., 2020) plus a number of contributions in article form describing and explaining the approach as well as its results so far (e.g. Bayrhuber et al., 2018; Bayrhuber and Frederking, 2019; Rothgangel and Frederking, 2019), some in English (e.g. Vollmer, 2014; Rothgangel and Vollmer, 2020) or in French (Vollmer, 2013). Extracts from the first two volumes mentioned here are in the process of being translated into English by the authors (cf. Vollmer and Rothgangel, forthcoming).

\section{Foundations of general subject didactics}

One of the reasons for the establishment of general subject didactics was the observation that the bulk of more recent research within the various subject didactics was no longer being processed or taken into account by scholars of general didactics. In that sense, GSD fills a task that was insufficiently performed by didactics as a branch of educational science (but cf. M. Meyer, 2016). The word 'general' within the term 'GSD' refers to the results of 'generalising' the subject-specific findings and theories of the many different subject didactics themselves, while also taking their subject-related peculiarities into account (Rothgangel, 2020). General subject didactics thus follows a logic that consists of the interplay of bottom-up comparisons and analyses and independent topdown reflections, focusing on teaching and learning within and beyond the different school subjects and on the specific theories about subject teaching and subject learning that one or another subject didactics had already developed about it (cf. Rothgangel and Vollmer, 2017, 2020).

The agency for relating the different subject-oriented disciplines to one another has created this new discipline, or rather meta-discipline, which does not fully exist yet but which is under way (among other things through discussions within and among the subject-didactic communities at large, nationally and now internationally). Areas of comparison so far have been historical developments, goal settings, influences from the state and political agendas, curricular expectations, research approaches applied, procedures for identifying teachable content, definition and evaluation of subject-specific teaching models and of (measurable) outcomes, and cooperation with other subjects in school or with neighbouring disciplines. Other areas like more teacher- and teachingrelated ones will follow. Through the different avenues of self-explanation and 
self-presentation, one particular common goal turned out to be of utmost joint interest and to become more substantial: in how far does each of the subjects involved think they contribute to the overall education (in the emphatic sense of the term) of the learners and how can we evidence this? More concretely: how does the next generation of students become equipped with the appropriate knowledge, tools, and intellectual plus moral strength for mastering their own future? How do they learn to think, to think in relations, constitute mental networks, become critical and autonomous through subject teaching and learning; how do they learn to communicate across social and cultural dividing lines and how does the official subject-based curriculum help them to do so?

\section{Subject-based education as Bildung: the core of all subject teaching and learning?}

At this point, the notion of 'subject-based education as Bildung' came up within the reports of individual subject didactics and thus the need for developing a theory which acknowledges the contribution of content teaching and learning for a comprehensive education of young learners. How could we bring the subject-based contributions into play, re-examining the concept of Bildung as a process and a product, redefining it in subject-specific terms, looking at both sides of the educational process, the personal and the functional one and the needs to go along with it, as mentioned earlier?

In her book The Educated Subject and the German Concept of Bildung (2016), Horlacher has given an impressive overview of the manifold meanings and uses of the term 'Bildung' at different times and in different socio-cultural contexts in which it was activated accordingly and revitalised again and again, not only in Germany or the German-speaking countries but also elsewhere on the globe. She was able to demonstrate that this continues to happen till this very day: the term seems to be flexible or fuzzy enough (on top of being 'trendy' again) to serve a number of functions for different philosophical traditions and lines of thinking over time, concerning education at large, by now also obligatory, state-governed education, even when it is based on assumptions of teachability, learnification, and outcomes orientation (cf. Horlacher, 2016, ch. 9, pp. 118-129). And indeed, for many of the subject didactics in Germany the notion of Bildung has become a synonym for the ultimate goal of their education - yet in a much wider sense than was traditionally meant. Accordingly, we developed an understanding of the notion which comprised not only the tacit forms of shaping the individual mind and personality of each learner in a purposeless manner (quasi as a side effect to content learning or as an addition to it). What seemed equally important was the development and unfolding of basic capacities or key competences and skills for personal development as a social being and for solving problems of the twenty-first century in a participatory, interactive way. In our revised and extended understanding of Bildung this part would imply the mental and socio-cultural equipment of 
individual learners for intercultural sensibility, for cooperation and democratic citizenship. ${ }^{10}$ Each subject would still be self-responsible for such a development towards autonomy and critical evaluation of knowledge and facts, but the school's (or society's) responsibility would be to offer rich opportunities for developing such critical and practical knowledge to be acquired by everyone. So in the end, we distinguished between two aspects of Bildung: personal versus functional Bildung, acknowledging that this notion can take on both meanings (cf. Frederking and Bayrhuber, 2017, who identified early as well as contemporary traces of both understandings). We are aware that this heuristic distinction could trigger wrong connotations: personal aspects of Bildung also rely on a sound knowledge base, whereas the acquisition of functional competencies and dispositions also require personal readiness and motivation and can imply corresponding benefits for the learner as a person, for his or her own personal development and cultivation. Possibly the different facets and dimensions of both sides are more interwoven than perceived so far, there seems to be no real contradiction between the two goals in this perspective. Many more theoretical advances in formulating an appropriate and precise theory of subject-based Bildung are still needed, of course.

As to the term 'knowledge', we can distinguish at least three different types: 'factual' knowledge (knowing that . . . which, however, involves always more than one single notion alone, which connects to a whole network of concepts), 'epistemic knowledge' (knowing how or how to, knowledge about the origins and procedures of gaining new pieces of knowledge) and 'applied knowledge' (knowing why or what for, including social use or misuse of knowledge, knowledge of the powerful vs. powerful knowledge; cf. Young, 2008; Muller and Young, 2019). This trifold division also reflects the structures of content, as analysed and distinguished as early as 1964 by Schwab: he distinguishes 'substantive' structures (conceptually organised, e.g. research results) from 'syntactic' ones (relating to the acquisition of knowledge). Both should be complemented, however, by 'applied' structures as a third type (cf. Bayrhuber, 2017) where knowledge is used for a number of purposes, among them uncovering problematic or false assumptions, finding out about wrong assertions or fake news, experiencing degrees of reliability and trustworthiness or checking its relevance. At least the last the two types of knowledge can be accounted for as elements of functional education as Bildung, since the learner is empowered and put into the position of acquiring and evaluating new knowledge or handling given/factual elements critically. This second element is clearly needed as a reflective mind with a firm critical attitude so to look through and overcome the simple and easily superficial structures of knowing that and knowing how. At the same time, this is a basic educational outfit for life, also against the misuse of knowledge by powerful others. It was the educational sociologist M. F. D. Young (2008) who introduced the term 'powerful knowledge' in this context in order to qualify the content basis as fundamental for learning for life. ${ }^{11}$ He triggered a whole debate about curriculum change and the reintroduction 
of specialised knowledge as equipment with appropriate tools (cf. "What Is Educationally Worthwhile Knowledge?” Derry, 2018; cf. also Vollmer, 2021).

In the course of our research, we became aware that in times of OECD and PISA the second meaning of Bildung, the functional one, is becoming more prominent in educational philosophy and practice: it is strongly connected with an extended literacy concept, originating from North America itself or at least from the anglophone world (Frederking and Bayrhuber, 2017) and more indirectly with the notion of competence (as contextualised ability, yet as a transferable disposition; cf. Vollmer, 2021). By focusing primarily on the many subject-based literacies at school, these can easily become the dominant goal or area of attention in modern, globalised education, while the original aspects of Bildung (associated with the unfolding of the person, with self-formation and self-cultivation) could become more easily overlooked, forgotten, or even endangered in the everyday practice of teaching for useful skills, measurable outcomes, and competences. On the other hand, mental procedures like inferencing, comparing, probability thinking, cultural-historical embedding, or even learning to learn could exactly become part of the personal qualities of Bildung. And, in the acquisition of functional literacies, in getting to know the basic epistemological structures of a field, the basic procedures of acquiring content knowledge, of using it and adding to it and thereby discovering even more of it, there is actually a personal educative dimension already implied in these activities. ${ }^{12}$ In that sense, personal aspects of Bildung partly happen within or through functional acquisition processes, as an aside or as a side product, so to speak - almost unintentionally at first, as a way of building up and unfolding critical, powerful knowledge in the students, provided they actively want, adopt, and support this in the longer run.

\section{General subject didactics as a developmental project}

General subject didactics, as illustrated, is a new approach, a new mode of thinking, comparing and generalising. It is a well-documented cross-disciplinary project of scholars within the German Association for Fachdidaktik, offered to subject-didactic communities worldwide. It has striking similarities with the network Knowledge and Quality across School Subjects and Teacher Education (KOSS), which operates even internationally and brings together three crossdisciplinary educational research groups rooted in several academic disciplines from Sweden, Finland, and England. They seek "to understand how educators and education systems can ensure that school-based knowledge building reaches its transformative potential" (cf. KOSS, 2020). In their work, they draw upon the concepts 'powerful knowledge' and 'epistemic quality' to help understand the qualities that knowledge building has when it is effective and empowering and how educational processes can build and develop these properties. ${ }^{13}$

As to general subject didactics in Germany, the methodological framework of this research approach has been thought through and described with care 
and precision, contrary to many projects of general didacticians where the methodological framing is simply left out or forgotten. The main basis of this qualitative research approach is that of the Grounded Theory (Strauss and Corbin, 1996, as one of several appropriate methodologies), by which the subject-based observations about subject-specific teaching, made within subject didactics, are once more observed on a higher level, compared, systematised, and generalised (actually a meta-analysis).

GSD is a powerful frame of reference in which the central questions of subject-based teaching and learning as well as the links beyond and across subjects are adequately dealt with. This is particularly true under the perspective of Bildung in the double sense as the overriding educational purpose. In this perspective, general didactics could become a relevant reference partner again for subject didactics, all the more if a meta-theoretical justification of general didactics is also winning ground and generalisable empirical results would be offered, based on comparison between subjects, subject didactics, and subject-specific modelling, similar to the self-understanding of GSD. General subject didactics is an abstract concept; it is not a new discipline, it is not institutionalised within university structures and will probably never be nor has it any equivalence in professorial posts. Rather, GSD represents a mode of comprehension and thinking (in the sense of Popper, 2009) or a mode of observing on three different levels, as outlined earlier according to Luhmann (1992), by which peculiarities and differences among individual subject didactics, their concrete theories and findings can be studied and made transparent through comparison. In that sense, GSD can also be paraphrased as a Theory of Subject-Matter Didactics (Rothgangel, 2020; Rothgangel and Vollmer, 2020).

The decisive point here is how general subject didactics will describe and justify the general dimensions within its meta-theory, whether or not it will be successful in identifying and characterising the different facets and aspects of subject-specific education as Bildung on a general level and put it into a convincing theory or theoretical frame of reference (fachliche Bildungstheorie). This is the major task at the moment. There are several sources possible on which to draw for such a theoretical construct:

1 Reported experiences from subject teachers (first order observations: a topic lending itself for deeper educational processing, materials, or goals cutting across subject-specific borderlines, cooperation with other subject teachers, team teaching, cross-curricular projects, etc.).

2 Self-analysis and reports from the different subject didactics (second order observations: concerning educational practices in the classroom, goals identified, research results, and above all theoretical modelling of the subjectspecific teaching-learning processes). This source is open to further findings, discoveries and reports (cf. the 17 contributions in Rothgangel et al., 2020 , on the state-of-the-art and the research perspectives of the respective subject didactics). 
3 Selected results from general subject didactics (third order observations, according to Luhmann, 1992), as presented selectively in Rothgangel et al. (2020), Rothgangel and Vollmer (2020) - especially in view of personal or functional education (Bildung). These illustrate the strength and productivity of a bottom-up procedure through comparison and analysis (based on the Grounded Theory) as much as of a top-down approach through theorising.

4 Systematic reconstruction of historical traces: what was understood by Bildung in earlier times of history until today? Can one identify a distinction between personal versus functional Bildung in the past, in the classical literature from the Middle Ages via Wilhelm von Humboldt till today? Can one find traces of 'subject-based education' as a task for schools or selflearning (cf. above all Frederking and Bayrhuber, 2017; see also Schneuwly and Vollmer, 2018). In this context, Baumert's theory of four "modes of world encounter" or of relating to the world (2002, p. 113) is helpful: it assumes that there are "horizons" of world knowledge and of understanding the world which are fundamental for education (in the sense of Bildung) and which cannot be replaced by one another nor anything else. This insight supports the survival of a general, canon-based (possibly domainoriented) curriculum.

5 Finally, anthropological dimensions (like rationality, reflexivity, or emotional balance) as much as basic socio-cultural ones (like discourse ability or acceptance of otherness/diversity) have to be checked for inclusion into such a list of components for a subject-based educational theory. Many more will be worked upon within the next months (cf. early reflections in Vollmer, 2013, 2014; more recently in Vollmer, forthcoming).

Only by shifting away from descriptive-analytical levels towards normative argumentation plus recourse to Baumert's modes of world encounter will a theory of education succeed in assigning a specific role and position for subjects or subject didactics in a future curriculum. Overall, there will be flexibility necessary between different methodological approaches: on the one hand, systematic-historical (re-)construction of subject-oriented facets of Bildung, inductive reasoning and analyses, generalised from specific observations and findings (bottom-up movement), and finally the level of theoretical construction and insight (hermeneutic procedures, top-down movement). All of these approaches can help to identify central elements for an extended understanding and conceptualisation of a subject-based education theory. We are looking for cognitive, emotional, physical, and interactional categories of Bildung which are cross-curricular and generic in nature, forming the basis for a learner's personal development and his/her empowerment simultaneously that help master future challenges and demands. Other components are self-reflective, critical, education towards autonomy, and citizenship. The publication of such a subjectbased theory of Bildung is planned for 2022 . 


\section{Outlook}

Resuming the research question which was posed in the Introduction: can subject didactics fill the gap which was left open by general didactics - at least in part? As we have demonstrated, a diversification and specialisation of different subject didactics can indeed be better equipped and respond more appropriately to the issues of content education, of researching within a limited area of concern and discussing goals and consequences in personal as well as functional terms. But it is only the scientific work on the "third level of observation" (Luhmann, 1992), the comparative subject didactic research within the framework of general subject sidactics, which allows us to look at the overall educative endeavours of the whole system and derive a theory of subject didactics from it. In connection with a newly developed approach of 'subject-based education as Bildung' we had to overcome (or surpass) the traditional 'Bildung-oriented Didaktik' in the version of Klafki and others in order to unfold an extended understanding of education, of didactics, and of subject didactics (deliberately spelled in an Anglicised form) in which Bildung figures differently, yet even more centrally as the goal of personal development and self-cultivation as much as of knowledge-building and functional empowerment through the acquisition of competencies. Such a theory of subject-based education as Bildung needs more clarification and theoretical precision, of course.

There are also a number of unsettled issues (theoretical and practical ones) in connection with the topic that we cannot deal with in this chapter. To tackle them requires a reconsideration of the whole educational system or systems plus reorganisation of curricula. One of them has to do with a reevaluation of what constitutes educationally worthwhile knowledge (cf. Derry, 2018; Muller and Young, 2019), in close relation with the concept of Bildung, as presented in this chapter (Vollmer, 2021). Another one has to do with a restructuring of the subjects or learning areas in school. In view of these complex issues, more general subject didactics is needed: advances in subject-based education theory as much as in empirical teaching and learning research, including design-based research, specifically geared to individual subjects.

Whether this is just a national agenda or a European one (cf. Hudson and Meyer, 2011, or Ligozat and Almqvist, 2018; Hordern, Muller and Deng, 2021) or whether it will even be possible to communicate and discuss these questions worldwide with some chances of mutual understanding remains to be seen (cf. Ligozat et al., forthcoming). The problems of different historical, cultural, and professional traditions remain and those of translation are also enormous (cf. Hopmann, 2007, 2015). Yet, we need precise terms for the international exchange on the topic. 'Subject(-matter) didactics' is already a compromise in translating the German term Fachdidaktik: it is an attempt to enable a more unified exchange and scientific communication across national borderlines, at least among those who are familiar with didactic thinking. The use of English as a lingua franca is different from that of British or American 
English: 'Subject Didactics' (or 'disciplinary didactics', as often labelled in other European contexts) is a paraphrase for what is usually thought of differently within many Anglo-Saxon communities, so it is not clear at all what meaning will be associated with that term or whether a common English denominator can (ever) be found and whether or not something like a scientific theory of teaching and learning in different content areas is jointly understood by it. Something similar applies to other notions like 'content', for example, where teachable content is normally derived in a double process of transformation, according to the didactic framework of thinking. Even in dealing with Shulman's notion of 'Pedagogical Content Knowledge' (PCK) there are serious problems of translation. As much as he tries to bring content, pedagogy, and teaching methods together in the mind of a teacher, his model does not capture enough of the interactive nature in the planning, teaching, learning, and evaluation processes along defined goals and areas of knowledge building. There is something important missing here, at least from a subject-didactic point of view: but how to express it in English? (cf. Vollmer and Klette, forthcoming).

It remains to be seen how we can revitalise the 'old' debate between 'Didaktik' versus 'curriculum' from the 1990s and turn it more productively than before (Westbury, 2000), also responding to newer developments in the large field of didactics. Hopmann sketches some of the dramatic changes which have taken place ever since. He argues that "the double game of curricula and testing is far from over" and that there are more theoretical efforts needed on both sides than ever before and even more dialogue in terms of international exchange of experiences, if we do not want "to lose our orientation on this rocky path" (2015, p. 20). Earlier, Siljander, Kivelä and Sutinen (2012) have already done some important philosophical groundwork for a potential meeting of continental European and North American minds, coming from two different cultures and educational backgrounds - at least for one aspect of Bildung in connection with the notion of growth and personal, individual maturity. The other dimension of Bildung in connection with literacy, with key competences and the needs of a modern society including economy and employability (as used by the OECD), still has to be explained better and integrated in theoretical terms, if the apparent contradictions between a humanistic (idealistic) approach and a social scientific one and thus between inner developments and capabilitiesfor mastering outer life are to be overcome. One of the points of reference should be the debates about PISA and the national as well as international comparative measurement approaches triggered by it (for Germany cf. Klieme et al., 2003, and more specifically Klieme and Hartig, 2007). The authors developed a more differentiated concept of Bildung or competence; they argued that each subject or area of learning must create its own competence model. For them, competence means "the ability of a person to cope with situational requirements" (Klieme and Hartig, 2007, p. 16). What exactly is the transformative power in that definition of competence? And does it still reflect Bildung, even in a functional sense? ${ }^{14}$ 
Since our discourse seems to be so very European (as didactic thinking is altogether), it is not easy to be properly understood in anglophone academic cultures and vice versa. But with the new tendencies of a globalised education taking place on both sides of the Atlantic, it is worth another try: we should indeed go one step further towards a deeper understanding of each other this time. In any case, the dialogue will be complex, if not complicated.

\section{Notes}

1 I gratefully acknowledge the cooperation with my colleagues Ulf Abraham, Horst Bayrhuber, Volker Frederking, Werner Jank, and Martin Rothgangel within our project General Subject Didactics, funded by the Association for Fachdidaktik, Germany. My contribution is partly based on our joint discussions and findings.

2 We will distinguish between the notion of 'Didaktik' (relating specifically to the discourse centred around Wolfgang Klafki and his theoretical work on material and formal Bildung or Allgemeinbildung respectively) and the English terms 'didactics' and 'subjectmatter didactics'. The latter two denote the science and art of teaching and learning in school and beyond in a general sense or in a domain-specific way, as long as teaching is planned, goal-oriented, and systematic. 'Didactics' and 'subject-matter didactics' or 'disciplinary didactics' are now largely being used in Europe for cross-cultural communication and could also become acceptable to native speakers of English. This distinction coincides with the usage indicated in the introduction of Krogh, Qvortrup, and Graf (this volume). Nevertheless, some scholars consider the term 'pedagogy' a possible equivalent for 'didactics' in English (cf. Vollmer, forthcoming).

3 Some critics mock that didactics without subject specificity is like knitting without wool.

4 This development was analysed by M. and H. Meyer in their joint publication of 2007 (p. 155) based on their observation of an increasing absence of the didactics of Wolfgang Klafki within the discourse of subject didactics in its different forms and communities.

5 The term 'pedagogy' as an academic discipline (and not only as an act of teaching) normally covers more scientific ground and addresses more issues of education than 'didactics', which deals more systematically with teaching and learning or instruction in institutional settings in a narrower sense. The latter notion does not exist within the English-speaking world, however, and certainly not in its comprehensive meaning. In any case, pedagogy comprises didactics and also specialised forms of teaching and learning (while many European scholars would rather talk about 'subject-matter didactics' or 'disciplinary didactics').

6 According to Thomas Kuhn (1962), old theories do not only die because they are outdated or cannot be confirmed by empirical data, but because the young, emergent researchers do not turn to them anymore - they turn to new paradigms with more precision and explanatory power. This could happen to general didactics: there seems to be little increase in new knowledge and understanding, instead repetition and new summaries of the old discourse (cf. Porsch, 2016).

7 There is no space here to outline the procedures or results of his study in more detail.

8 It is striking that Scholl used the same theoretical framing and methodology for his re-analysis of some of the important didactic models in Germany and for building his 'Meta-Theory of General Didactics', as did a group of subject didacticians in developing their '(Meta-)Theory of Subject-Matter Didactics', namely by comparing and identifying the differences and commonalities among the existing subject didactic disciplines and by theorising those.

9 Outside of Germany, the term 'disciplinary didactics' instead of 'subject didactics' is also used (in France and in parts of Scandinavia as well) - the problem being that it brings the content or knowledge to be taught at school into too close a relationship with 'academic' 
disciplines and their findings (at least in German). If the term 'discipline', however, denotes the subdivisions of content structures or the different areas/domains of knowledge at university and equally so in school (cf. German: Fach/pl. Fächer, Wissenschaftsfach vs. Schulfach), both terms describing different specialised fields of teaching and learning content in school are acceptable (Vollmer, forthcoming). In any case, scientific content has to undergo several transformations in order to become teachable and relevant for different groups of learners within school subjects (cf. Schneuwly, this volume).

10 In order to prepare for this, learners have to become active participants within the teaching-learning processes themselves.

11 The notion of 'powerful knowledge' in connection with curriculum studies opens a totally new debate which cannot be dealt with here; but see Young (2008), Young and Muller (2016), and Guile, Lambert and Reiss (2018); see also Vollmer (2021).

12 The contribution of English as L2 for a comprehensive education (Bildung) of learners can be exemplified here. English contributes to intercultural sensitivity, to structuring and transforming thoughts into text, to experience as a system or to analyse (subject) discourse critically and thus to develop also the personalities. But English as a subject also fosters the formation of relevant socio-cultural knowledge by language use: critical capacities and skills, knowing conventions, comparing expressions and language systems, knowing how to learn a language, etc. (Vollmer and Vogt, 2020).

13 The three research groups, ROSE (Research on Subject-specific Education), SSR G (Subject Specialism Research Group), and HuSoEd (Research Community for Humanities and Social Sciences Education), within KOSS focus "on the ways in which knowledge itself is transformed as it is re-contextualized at individual, institutional and societal levels. Our long-term goal is to contribute to meeting the needs of future citizens by producing new knowledge about educational processes; this will have the potential to improve education by supporting the development of powerful subject disciplinary knowledge in schools" (KOSS, 2020; cf. also Gericke et al., 2018; Hudson, 2019).

14 Horlacher rightly points out that the term 'Bildung' has lost "none of its brilliance and public efficacy for both defenders and critics of PISA. Defenders wish to replace Bildung with the term competence, thus overcoming its perceived limitations as an ambiguous and yet culturally specific term; critics wish to restore the classical concept of Bildung" (2016, pp. 125-126). Both resort to the notion when it comes to discussing normative guidelines and perspectives.

\section{References}

Abraham, U. and Rothgangel, M. (2017). Fachdidaktik im Spannungsfeld von "Bildungswissenschaft" und "Fachwissenschaft" [Subject didactics between the poles of the educational sciences and academic disciplines]. In: H. Bayrhuber, U. Abraham, V. Frederking, W. Jank, M. Rothgangel and H. J. Vollmer, eds., Auf dem Weg zu einer Allgemeinen Fachdidaktik [Towards a general subject didactics]. Muenster: Waxmann, pp. 15-21.

Baumert, J. (2002). Deutschland im internationalen Bildungsvergleich [Germany's education in international comparison]. In: N. Killius, J. Kluge and L. Reisch, eds., Die Zukunft der Bildung [The future of education]. Frankfurt am Main: Suhrkamp, pp. 100-150.

Bayrhuber, H. (2017). Allgemeine Fachdidaktik im Spannungsfeld von Fachwissenschaft und Fachdidaktik als Modellierungswissenschaft [General subject didactics between the poles of academic disciplines and subject didactics as a modelling science]. In: H. Bayrhuber, U. Abraham, V. Frederking, W. Jank, M. Rothgangel and H. J. Vollmer, eds., Auf dem Weg zu einer Allgemeinen Fachdidaktik [Towards a general subject didactics]. Muenster: Waxmann, pp. 161-178. 
Bayrhuber, H., Abraham, U., Frederking, V., Jank, W., Rothgangel, M. and Vollmer, H. J. (2017). Aufdem Weg zu einer Allgemeinen Fachdidaktik. Allgemeine Fachdidaktik. Bd. 1 [Towards a general subject didactics. General subject didactics. Vol. 1]. Muenster: Waxmann.

Bayrhuber, H., Abraham, U., Frederking, V., Jank, W., Rothgangel, M. and Vollmer, H. J. (2018). Fachlichkeit im Horizont der Allgemeinen Fachdidaktik [Disciplinarity on the horizon of general subject didactics]. In: M. Martens, K. Rabenstein, K. Bräu, M. Fetzer, H. Gresch, I. Hardy and C. Schelle, eds., Konstruktionen von Fachlichkeit [Constructions of subject-didactic dimensions]. Bad Heilbrunn: Klinkhardt, pp. 42-54.

Bayrhuber, H. and Frederking, V. (2019). Fachdidaktisches Wissen und fachliche Bildung: Ein Klärungsversuch im Horizont der Allgemeinen Fachdidaktik [Subject-didactic knowledge and subject-specific Bildung/education: Clarification attempt under the perspective of /in the context of general subject didactics]. Jahrbuch für Allgemeine Didaktik 2019, thematic section. Baltmannsweiler: Schneider, pp. 10-29.

Benner, D. (1987). Allgemeine Pädagogik: Eine systematisch-problemgeschichtliche Einführung in die Grundstruktur pädagogischen Denkens und Handelns [General Pedagogy: A systematic and historical problem-oriented introduction into the basic structures of pedagogical thinking and acting]. Weinheim: Juventa.

Blankertz, H. (1973). Theorien und Modelle der Didaktik [Theories and models of Didaktik], 7th ed. Munich: Juventa.

Coriand, R. (2017). Allgemeine Didaktik: Ein erziehungstheoretischer Umriss [General didactics: Outline of a philosophy of education], 2nd ed. Stuttgart: Kohlhammer.

Cramer, C. and Schreiber, F. (2018). Subject didactics and educational sciences: Relationships and their implications for teacher education from the viewpoint of educational sciences. Research in Subject-Matter Teaching and Learning (RISTAL), 1, pp. 150-164.

Derry, J. (2018). What is educationally worthwhile knowledge? Revisiting the case for powerful knowledge. In: D. Guile, D. Lambert and M. J. Reiss, eds., Sociology, curriculum studies and professional knowledge: New perspectives on the work of Michael Young. London: Routledge, pp. 84-96.

Flitner, W. (1961). Die gymnasiale Oberstufe. Heidelberg: Quelle \& Meyer.

Frederking, V. and Bayrhuber, H. (2017). Fachliche Bildung: Auf dem Weg zu einer fachdidaktischen Bildungstheorie [Subject-/content-based Bildung: Towards a subject-didactic theory of Bildung]. In: H. Bayrhuber, U. Abraham, V. Frederking, W. Jank, M. Rothgangel and H. J. Vollmer, eds., Auf dem Weg zu einer Allgemeinen Fachdidaktik [Towards a general subject didactics]. Muenster: Waxmann, pp. 205-247.

Gericke, N., Hudson, B., Olin-Scheller, C. and Stolare, M. (2018). Powerful knowledge, transformations and the need for empirical studies across school subjects. London Review of Education, 16(3), pp. 428-444.

Guile, D., Lambert, D. and Reiss, M. J., eds. (2018). Sociology, curriculum studies and professional knowledge: New perspectives on the work of Michael Young. London: Routledge.

Hattie, J. (2008). Visible learning. London: Routledge.

Heimann, P., Otto, G. and Schulz, W. (1979). Unterricht: Analyse und Planung [Teaching: Analysis and planning], 10th ed. Hannover: Schroedel.

Heursen, G. (2005). Didaktischer Frühling oder ein Abschied in den Winter? Eine Sammelbesprechung über vier neue Einführungen in die Didaktik und ebenso viele Fragen [Didactic springtime or farewell into winter? A collective review of four new introductions into Didactics and as many questions]. Erziehungswissenschaftliche Revue, 4(3). Available at: www.klinkhardt.de/ewr/40725356.html [Accessed 22 August 2020]. 
Hopmann, S. (2007). Restrained teaching: The common core of Didaktik. European Educational Research Journal, 6(2), pp. 109-124. https://doi.org/10.2304/eerj.2007.6.2.109.

Hopmann, S. (2015). 'Didaktik meets Curriculum' revisited: Historical encounters, systematic experience, empirical limits. Nordic Journal of Studies in Educational Policy, 1(1), pp. 14-21. https://doi.org/10.3402/nstep.v1.27007.

Hordern, J., Muller, J. and Deng, Z., eds. (2021). Towards powerful educational knowledge? Special issue of the Journal of Curriculum Studies.

Horlacher, R. (2016). The educated subject and the German concept of Bildung: A comparative cultural history. London and New York: Routledge.

Hudson, B. (2019). Epistemic quality for equitable access to quality education in school mathematics. Journal of Curriculum Studies, 51(4), pp. 437-456. https://doi.org/10.1080/ 00220272.2019 .1618917$.

Hudson, B. and Meyer, M., eds. (2011). Beyond fragmentation: Didactics, learning and teaching in Europe. Opladen: Budrich.

Jank, W. and Meyer, H. (2011). Didaktische Modelle [Didactic models/modelling], 10th ed. Berlin: Cornelsen. [New edition planned for 2021].

Klafki, W. (1996). Neue Studien zur Bildungstheorie und Didaktik: Zeitgemäße Allgemeinbildung und kritisch-konstruktive Didaktik [New studies into a theory of Bildung and Didaktik: Contemporary general education and critical-constructive Didaktik], 5th ed. Weinheim: Beltz.

Klieme, E., Avenarius, H., Blum, W., Döbrich, P., Gruber, H., Prenzel, M., Reiss, K., Riquarts, K., Rost, J., Tenorth, H.-E. and Vollmer, H. J. (2003). Zur Entwicklung nationaler Bildungsstandards: Eine Expertise [The development of national educational standards: An expertise]. Bonn: Federal Ministry of Education and Research.

Klieme, E. and Hartig, J. (2007). Kompetenzkonzepte in den Sozialwissenschaften und im erziehungswissenschaftlichen Diskurs [Concepts of competence in the social sciences and in the educational scientific discourse]. Zeitschrift für Erziehungswissenschaft, special issue 10, pp. 11-29.

KOSS (Knowledge and Quality across School Subjects and Teacher Education). (2020). Available at: www.kau.se/en/rose/external-relations/knowledge-and-quality-across-schoolsubjects-and-teacher-education-koss [Accessed 22 August 2020].

Kuhn, T. S. (1962). The structure of scientific revolutions. Chicago, IL: University of Chicago Press.

Ligozat, F. and Almqvist, J., eds. (2018). Didactics: Learning and teaching, special issue of the European Educational Research Journal, 17(1).

Ligozat, F., Almqvist, J., Klette, K. and Rakhkochkine, A., eds. (forthcoming). Didactics in a changing world: European perspectives on teaching, learning and the curriculum. London: Routledge.

Luhmann, N. (1992). Die Wissenschaft der Gesellschaft [Theory of society]. Frankfurt am Main: Suhrkamp.

Meyer, H. (forthcoming). Laudatio für Werner Jank: Balancieren zwischen Fach- und Allgemeindidaktik [Address in honour of Werner Jank: Finding a balance between subject and general didactics]. Unpublished lecture, given 15 February 2020 at Frankfurt University of Music and Performing Arts. [To be published in 2021].

Meyer, M. (2016). Rückständig oder zukunftsweisend? Reflexionen zum Potential der Allgemeinen Didaktik [Backwards or forward-looking/future-oriented? Reflections on the potential of general didactics]. In: A. Wegner, ed., Allgemeine Didaktik: Praxis, Positionen, Perspektiven [General didactics: Practice, positions, perspectives]. Opladen: Budrich, pp. $49-86$.

Meyer, M. and Meyer, H. (2007). Wolfgang Klafki: Eine Didaktik für das 21. Jahrhundert? [Wolfgang Klafki: A Didaktik for the 21st century?]. Weinheim: Beltz. 
Meyer, M. and Meyer, H. (2009). Totgesagte leben länger! Oder: Hat es in der Allgemeinen Didaktik einen Erkenntnisfortschritt gegeben? [The condemned live longer! Or: Has there been epistemic progress in general didactics?]. In: B. Wischer and K.-J. Tillmann, eds., Erziehungswissenschaft auf dem Prüfstand [Educational science under close scrutiny]. Weinheim: Juventa, pp. 97-128.

Meyer, M. and Reinartz, A., eds. (1998). Bildungsgangdidaktik: Denkanstöße für pädagogische Forschung und schulische Praxis [Didactics of educational development: Impulses for pedagogical research and practice in school]. Opladen: Leske + Budrich.

Muller, J. and Young, M. (2019). Knowledge, power and powerful knowledge re-visited. The Curriculum Journal [online], 30(2), pp. 196-214. https://doi.org/10.1080/09585176. 2019.1570292.

Popper, K. (2009). Vermutungen und Widerlegungen: Das Wachstum der wissenschaftichen Erkenntnis [Conjectures and refutations: The growth of scientific knowledge], 2nd ed. Tübingen: Mohr Siebeck.

Porsch, R., ed. (2016). Einführung in die Allgemeine Didaktik: Ein Lehr- und Arbeitsbuch für Lehramtsstudierende [Introduction into general didactics: A textbook and workbook for students of teacher education]. Muenster: Waxmann.

Prediger, S., Leuders, T. and Rösken-Winter, B. (2017). Drei-Tetraeder-Modell der gegenstandsbezogenen Professionalisierungsforschung [The three-tetrahedon-model of contentbased professionalisation research]. Jahrbuch für Allgemeine Didaktik 2017, pp. 159-177.

Rothgangel, M. (2017). Allgemeine Fachdidaktik im Spannungsfeld von Fachdidaktiken und Allgemeiner Didaktik [General Subject Didactics between subject Didactics and General Didactics]. In: H. Bayrhuber, U. Abraham, V. Frederking, W. Jank, M. Rothgangel and H. J. Vollmer, eds., Auf dem Weg zu einer Allgemeinen Fachdidaktik [Towards a general subject didactics]. Muenster: Waxmann, pp. 147-160.

Rothgangel, M. (2020). Allgemeine Fachdidaktik als Theorie der Fachdidaktiken [General subject didactics as a theory of subject didactics]. In: M. Rothgangel, U. Abraham, H. Bayrhuber, V. Frederking, W. Jank and H. J. Vollmer, eds., Lernen im Fach und über das Fach hinaus: Bestandsaufnahmen und Forschungsperspektiven aus 17 Fachdidaktiken im Vergleich. [Learning within and beyond a school subject: State of the art and research perspectives of 17 subject didactics compared/in comparison]. Muenster: Waxmann, pp. 581-598.

Rothgangel, M., Abraham, U., Bayrhuber, H., Frederking, V., Jank, W. and Vollmer, H. J., eds. (2020). Lernen im Fach und über das Fach hinaus: Bestandsaufnahmen und Forschungsperspektiven aus 17 Fachdidaktiken im Vergleich. Allgemeine Fachdidaktik. Bd. 2 [Learning within and beyond a school subject: State of the art and research perspectives of 17 subject didactics compared. General subject didactics. Vol. 2]. Muenster: Waxmann. (2nd ed. in 2021).

Rothgangel, M. and Frederking, V. (2019). Zeitgemäße schulische Inhalte aus Sicht der Allgemeinen Fachdidaktik: Ein Klärungsversuch am Beispiel digitaler fachlicher Bildung [Contemporary teaching content from the point of view of General Subject Didactics: Clarification attempt, using the example of digital subject-specific education]. In: L. Haas, K. Zierer and D. Behrens, eds., Unterrichten wir das "Richtige"? - Die Frage nach zeitgemäßen Bildungsinhalten in der Schule [Do we teach the right content? - The issue of appropriate educational content in school]. Jahrbuch für Allgemeine Didaktik 2018. Baltmannsweiler: Schneider, pp. 15-26.

Rothgangel, M. and Vollmer, H. J. (2017). Vergleichende Beobachtungen: Ausgangspunkte [Comparative Observations: Starting Points]. In: H. Bayrhuber, U. Abraham, V. Frederking, W. Jank, M. Rothgangel and H. J. Vollmer, eds., Auf dem Weg zu einer Allgemeinen Fachdidaktik [Towards a General Subject Didactics]. Muenster: Waxmann, pp. 22-30. 
Rothgangel, M. and Vollmer, H. J. (2020). Towards a theory of subject-matter didactics. Research in Subject-Matter Teaching and Learning (RISTAL), 3, pp. 126-151. https://doi. org $/ 10.23770 / \mathrm{rt} 1838$.

Schneuwly, B. (2011). Subject didactics: An academic field related to the teacher profession and teacher education. In: B. Hudson and M. Meyer, eds., Beyond fragmentation: Didactics, learning and teaching in Europe. Opladen: Budrich, pp. 275-286.

Schneuwly, B. and Vollmer, H. J. (2018). Bildung and subject didactics: Exploring a classical concept for building new insights. European Educational Research Journal, 17(1), pp. 37-50.

Scholl, D. (2018). Metatheorie der Allgemeinen Didaktik: Ein systemtheoretisch begründeter Vorschlag [A meta-theory of general didactics: A proposal based on system theory]. Bad Heilbrunn: Klinkhardt.

Schulz, W. (1991). Ein Hamburger Modell der Unterrichtsplanung [The Hamburg model of lesson planning]. In: B. Adl-Amini and R. Künzli, eds., Didaktische Modelle und Unterrichtsplanung [Didactic models and lesson planning], 3rd ed. Munich: Juventa, pp. 49-87.

Schwab, J. J. (1964). The structure of the disciplines: Meaning and significance. In: G. W. Ford and L. Pugno, eds., The structure of knowledge and the curriculum. Chicago, IL: Rand McNally, pp. 1-30.

Seel, N. M. and Zierer, K. (2018). Den "guten” Unterricht im Blick. Oder: Warum die Allgemeine Didaktik unersetzlich ist [Focusing on "good" instruction. Some thoughts on why general pedagogy is indispensable]. Beiträge zur Lehrerinnen- und Lehrerbildung (BzL), 36(3), pp. 378-389.

Siljander, P., Kivelä, A. and Sutinen, A., eds. (2012). Theories of Bildung and growth: Connections and controversies between continental educational thinking and American pragmatism. Rotterdam: Sense Publishers.

Strauss, A. and Corbin, J. (1996). Grounded Theory: Grundlagen qualitativer Sozialforschung [Grounded theory: Basics of qualitative research]. Weinheim: Beltz.

Terhart, E. (2018). Allgemeine Didaktik und Unterrichtstheorie im deutschsprachigen Raum: Beobachtungen und Einordnungen [General didactics and theory of teaching within German-speaking countries: Observations and framing]. In: D. Benner, H. Meyer, Z. Peng and Z. Li, eds., Beiträge zum Chinesisch-Deutschen Didaktik-Dialog [Contributions to the Chinese-German dialogue on didactics]. Bad Heilbrunn: Klinkhardt, pp. 83-97.

Terhart, E. (2019). Didaktik: Eine Einführung [Didactics: An introduction], New ed. Stuttgart: Reclam.

Vollmer, H. J. (2013). Didactique disciplinaire en Allemagne: développement et perspectives [Subject didactics in Germany: Developments and perspectives]. In: J.-L. Dorier, F. Leutenegger and B. Schneuwly, eds., Didactique en construction - Constructions en didactique(s) [Didactics under construction - constructions of didactics]. Brussels: De Boeck, pp. 39-62.

Vollmer, H. J. (2014). Fachdidaktik and the development of a generalised subject didactics in Germany. Éducation et Didactique, 8(1), pp. 23-34. https://doi.org/10.4000/ educationdidactique. 1861.

Vollmer, H. J. (2017). Zur jüngeren Entwicklung der Fachdidaktiken in Deutschland [Recent developments of subject didactics in Germany]. In: H. Bayrhuber, U. Abraham, V. Frederking, W. Jank, M. Rothgangel and H. J. Vollmer, eds., Auf dem Weg zu einer Allgemeinen Fachdidaktik [Towards a general subject didactics]. Muenster: Waxmann, pp. 11-14.

Vollmer, H. J. (2021). Powerful educational knowledge through subject didactics and general subject didactics. Recent developments in German-speaking countries. Journal of 
Curriculum Studies, special issue, Towards Powerful Educational Knowledge? Ed. by J. Hordern, J. Muller and Z. Deng (2021), 18 pp.

Vollmer, H. J. (forthcoming). Issues of conceptual German-English translation: Didactics, education, pedagogy, Bildung: Cultural embeddings - Intercultural discourse. In: H. J. Vollmer and M. Rothgangel, General Subject Didactics: Theoretical Foundations - Empirical Findings. Muenster: Waxmann.

Vollmer, H. J. and Klette, K. (forthcoming). Pedagogical content knowledge and subject didactics - an intercontinental dialogue? In: F. Ligozat, J. Almqvist, K. Klette and A. Rakhkochkine, eds., Didactics in a changing world: European perspectives on teaching, learning and the curriculum. London: Routledge.

Vollmer, H. J. \& Rothgangel. M. (forthcoming). General Subject Didactics: Theoretical Foundations - Empirical Findings. Muenster: Waxmann.

Vollmer, H. J. and Vogt, K. (2020). Englischdidaktik: Bestandsaufnahme und Forschungsperspektiven [Teaching and learning English as a foreign language (in Germany): State of the art and research perspectives]. In: M. Rothgangel, U. Abraham, H. Bayrhuber, V. Frederking, W. Jank and H. J. Vollmer, eds., Lernen im Fach und über das Fach hinaus: Bestandsaufnahmen und Forschungsperspektiven aus 17 Fachdidaktiken im Vergleich. [Learning within and beyond a school subject: State of the art and research perspectives of 17 subject didactics compared.]. Muenster: Waxmann, pp. 103-131.

von Hentig, H. (1996). Bildung. Munich: Hanser.

Wernke, S., Werner, J. and Zierer, K. (2015). Heimann, Schulz oder Klafki? Eine quantitative Studie zur Einschätzung der Praktikabilität allgemeindidaktischer Planungsmodelle [Heimann, Schulz or Klafki? A quantitative study for evaluating the practicality of general didactic planning models]. Zeitschrift für Pädagogik, 61(3), pp. 429-451.

Westbury, I. (2000). Teaching as a reflective practice: What might Didaktik teach curriculum? In I. Westbury, S. Hopmann and K. Riquarts, eds., Teaching as reflective practice: The German Didaktik tradition. Mahwah: Lawrence Erlbaum, pp. 15-39.

Young, M. F. D. (2008). Bringing knowledge back in: From social constructivism to social realism in the sociology of education. Oxon: Routledge.

Young, M. F. D. and Muller, J. (2016). Curriculum and the specialization of knowledge: Studies in the sociology of education. London: Routledge.

Zierer, K. and Wernke, S. (2013). Völlig unbrauchbar?! Zur Praktikabilität allgemeindidaktischer Modelle: Ergebnisse einer qualitativen Studie [Completely useless?! Practicability of general didactic models: Results from a qualitative study]. Pädagogische Rundschau, 67(2), pp. 143-160. 